Kredo 3 (2020)
KREDO: Jurnal Ilmiah Bahasa dan Sastra
Terakreditasi Sinta 4 berdasarkan Keputusan Direktorat
Jenderal Penguatan Riset dan Pengembangan,
Kementerian Riset, Teknologi dan Pendidikan Tinggi
Republik Indonesia
Nomor: 23/E/KPT/2019. 08 Agustus 2019
https://jurnal.umk.ac.id/index.php/kredo/index

\title{
ANALISIS PENAMAAN KEDAI KOPI DI SURABAYA: KAJIAN ETNOLINGUISTIK
}

\author{
Marisa Puteri Sekar Ayu Santosa \\ Email: santosa.marisa05@gmail.com
}

Prodi S2 Magister Ilmu Linguistik, Fakultas Ilmu Budaya Universitas Airlangga, Indonesia.

Info Artikel

Sejarah Artikel

Diterima $19 \mathrm{Mei}$

2020

Disetujui $21 \mathrm{Mei}$

2020

Dipublikasikan 27

Mei 2020

Keywords

etnolinguistics, mea

ning, naming

process, semantic

Kata Kunci

Etnolinguistik,

makna, proses

penamaan,

semantik.

\section{Abstract}

Naming process can be stated as a hope, that is why it is important to think more in giving name for something or labeling things. It can be shown in the naming process of the business, one of the business which needs naming process is coffee shop. Coffee shop becomes a new trend in Surabaya lately. The changing era makes naming process for coffee shops more diverse. The coffee shops' naming not only uses Indonesian, but they use local language and foreign language, and this phenomenon is really interesting to be studied. The purpose of this research is to observe the meaning of the coffee shops from the semantic side. The researcher used ten coffee shops in Surabaya which have "feeling" theme. After did the research by adding the interview with the owners, it can be concluded that the naming process of the coffee shops contain the owner's hopes and explaining the concept of the coffee shop itself.

\begin{abstract}
Abstrak
Nama bisa dikatakan sebagai sebuah harapan, oleh sebab itu setiap orang tidak akan sembarangan dalam memberikan nama-nama tertentu untuk melabeli sesuatu. Hal ini terlihat pada penamaan nama dari sebuah usaha atau bisnis, salah satunya adalah usaha kedai kopi yang sedang marak di Surabaya. Perkembangan zaman menyebabkan pemberian nama pada kedai kopi kian beragam. Nama-nama kedai kopi tersebut tidak hanya memakai bahasa Indonesia, tetapi ada pula yang memakai bahasa daerah dan bahasa asing, dan hal itu sangat menarik untuk dikaji.Tujuan dari penulisan penelitian ini adalah ingin melihat makna-makna dan latar belakang yang terkandung di dalam penamaan kedai kopi dari sis semantik. Dalam penelitian ini, peneliti menggunakan sepuluh kedai kopi di Surabaya yang mempunya tema "perasaan". Setelah dilakukan analisis dengan menambahkan data penguat berupa wawancara dengan pemilik, dapat disimpulkan bahwa penamaan dari kedai kopi ini memiliki makna harapan dari pemiliknya dan menggambarkan konsep yang melatarbelakangi sang pemilik dalam membuka kedai kopi tersebut.
\end{abstract}




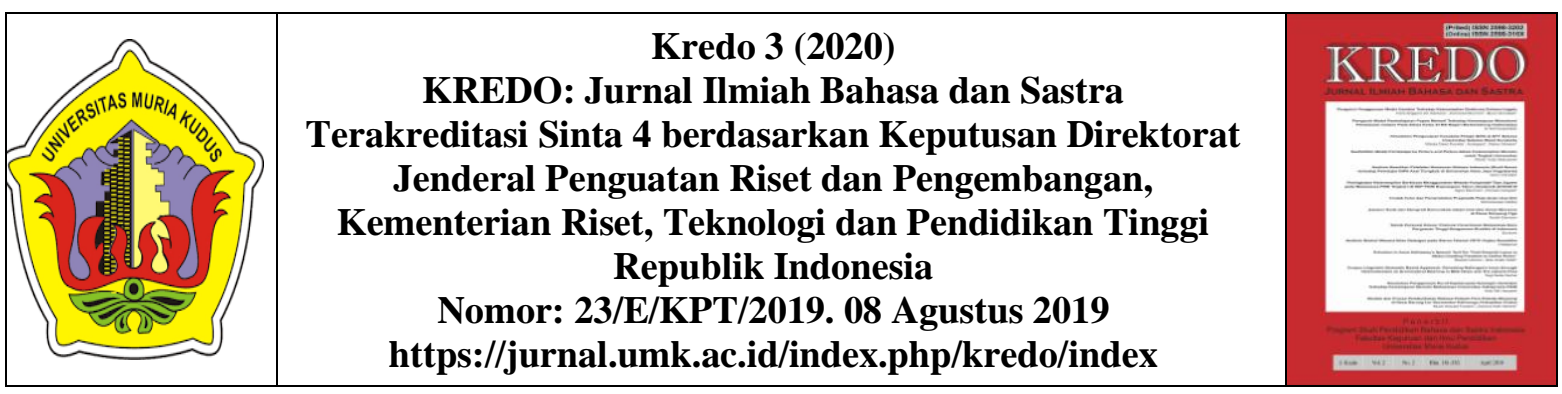

\section{PENDAHULUAN}

Segala sesuatu yang ada di dunia ini memiliki nama. Banyak masyarakat yang menganggap nama menjadi sebuah harapan dan keinginan dari si pemberi nama, oleh sebab itu orang-orang tidak sembarangan dalam memberikan namanama tertentu untuk melabeli sesuatu. Hal ini sering ditemukan tidak hanya pada nama seorang anak, tetapi juga banyak terjadi pada nama sebuah usaha atau bisnis. Salah satunya adalah namanama yang digunakan untuk melabeli sebuah . Seperti yang terlihat di Surabaya, fenomena penamaan usaha kedai kopi yang kian marak di Surabaya.

Seperti yang terlihat beberapa tahun belakangan, tak hanya menjadi sebuah kebiasaan, minum kopi mulai bertransformasi menjadi sebuah gaya hidup untuk anak muda jaman sekarang. Hal ini didukung oleh perkembangan kedai-kedai kopi yang kian menjamur di kota Surabaya. Sebuah nama digunakan untuk membedakan satu sama lain agar seseorang dapat dengan mudah mengenalinya. Djajasudarma (1999) menyatakan bahwa nama-nama muncul akibat dari kehidupan manusia yang komplek dan beragam serta alam sekitar manusia yang berjenis-jenis. Oleh karena itu, muncul nama-nama kelompok seperti, benda, tempat, dan alam yang dihasilkan dari ide tau gagasan yang didalamnya mempunyai makna dan menunjukkan identitas dari benda tersebut.

Perubahan zaman menyebabkan pemberian nama pada kedai kopi kian beragam. Nama-nama kedai kopi tersebut tidak hanya memakai bahasa Indonesia, tetapi ada pula yang memakai bahasa daerah dan bahasa asing. Hal itu sangat menarik untuk dikaji agar masyarakat umum dapat mengetahui makna dan latar belakang dibalik penamaan kedai kopi tersebut.

Memang kedai kopi sudah ada sejak dahulu, akan tetapi sebelumnya kopi hanya sebatas minuman bagi orang tua dan pria dewasa saja yang biasanya diminum di kedai-kedai tradisional. Saat ini kedai kopi menawarkan modernitas tidak hanya dari segi penampilan kedai, tetapi juga sajian kopi yang dikemas dan diolah dengan menggunakan berbagai metode. Nama-nama kedai kopi itupun terbilang unik, sebut saja Kopi Kenangan, Janji Jiwa, Lain Hati, Titik Koma, dan sebagainya. Setiap kedai kopi mempunyai ciri khas yang berbeda-beda yang ingin ditonjolkan selain dari menu yang tersedia, sebuah nama pun bisa mempengaruhi. Sebuah proses penamaan pada suatu benda termasuk dalam bagian dari kebudayaan.

Budaya nama-nama kedai kopi bisa dipahami sebagai penamaan (naming process) yaitu sebuah proses penggunaan bahasa yang paling awal dalam keadaan manusia. Menurut Sibarani (2006), terdapat 2 macam proses penamaan, yakni common meaning atau proses penamaan untuk benda-benda umum sehingga membentuk kata-kata benda umum (common nouns) dan proper naming atau proses penamaan untuk nama-nama diri sehingga membentuk kata benda nama diri (proper nouns). Proper naming lebih berhubungan dengan kajian budaya yang akan diteliti. Karena nama diri (proper name) tidak hanya untuk nama orang tetapi bisa digunakan untuk nama-nama kedai kopi.

Untuk penelitian kali ini, penulis telah membuat list nama-nama dari beberapa kedai kopi yang sedang naik daun di wilayah Surabaya, dan penulis 


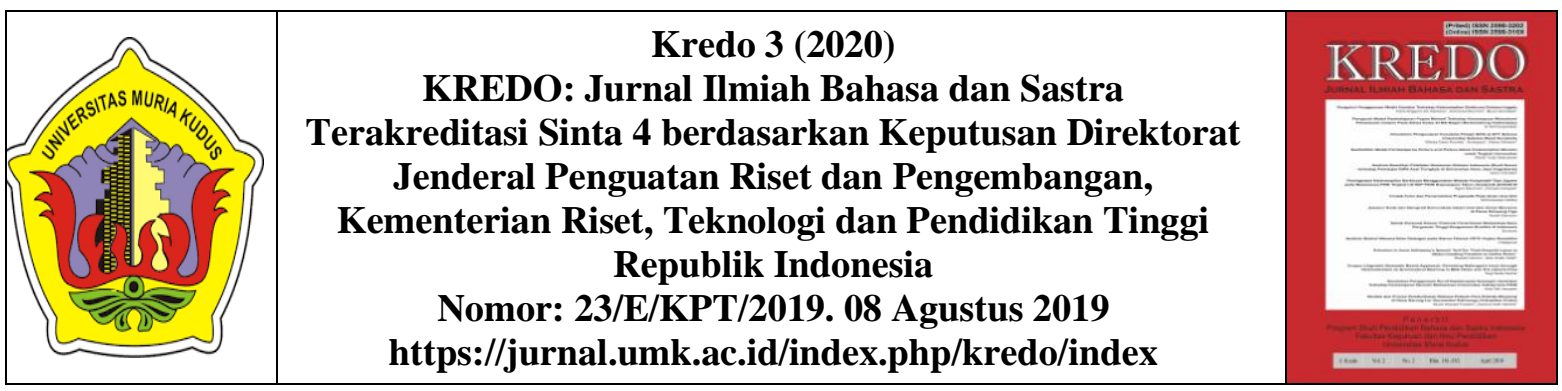

tertarik hanya pada penamaan yang memakai kategori "perasaan". Telah ditemukan 10 kedai kopi tersebut, yakni: Janji Jiwa, Lain Hati, Kopi Kenangan, Kopi Kangen, Pelipur Lara, Awal Cerita Kopi, Kopi Teman Baik, Kopi Teman Mikir, Kopi Koko Nakal, dan Titik Koma Coffee. Fenomena ini merupakan fenomena baru di Surabaya, karena pada umumnya kedai kopi mengangkat unsur yang berhubungan dengan kopi. Seperti yang telah dijelaskan diatas, proper naming merupakan sebuah nama diri yg membentuk kata benda nama diri dan lebih berhubungan dengan budaya. Dalam penelitian ini, penulis memiliki tujuan untuk mendeskripsikan jenis makna nama-nama kedai kopi yang ada di kota Surabaya.

Koentjaraningrat

menyatakan bahwa pada hakikatnya kebudayaan adalah keseluruhan sistem gagasan, tindakan, dan hasil karya manusia dalam rangka kehidupan masyarakat yang dijadikan milik dari manusia dengan belajar. Ada tujuh unsur kebudayan yang universal: bahasa, sistem pengetahuan, organisasi sosial, sistem peralatan hidup dan teknologi, sistem pencarian hidup, religi, dan kesenian. Bahasa merupakan salah satu bagiannya. Dalam menjembatani antara bahasa dan budaya dalam fenomena penamaan dibutuhkan sebuah ilmu kebahasaan yang juga berhubungan dengan budaya, yaitu etnolinguistik.

Menurut Abdullah (2013), etnolinguistik merupakan sebuah ilmu kebahasaan yang menitikberatkan pada dimensi bahasa seperti sosial dan budaya. Selain itu menurut Haugen (dalam Aron 2007) menyatakan bahwa etnolingustik bisa diartikan sebagai salah satu kajian dari beberapa kajian ekologi bahasa yang sudah mapan. Disini
Haugen menyebutkan bahwa etnolinguistik ini membedah dan memilah-milah penggunaan bahasa, cara dan pola pikir dalam katian dengan pola penggunaan bahasa, cara dan pola pikir dala kaitan dengan pola penggunaan bahasa, bahasa-bahasa ritual, dan kreasi wacana. Ditambahkan pula oleh Abdullah (2014), bahwa orientasi terpenting dalam kajian etnolinguistik sangat membutuhkan pemahaman tentang semantik leksikal.

Menurut Djajasudarma (1999), semantik di dalam bahasa Indonesia berasal dari bahasa Inggris semantics, dari bahasa Yunani sema (nomina) yang berarti 'tanda', atau dari verba semaino yang berarti 'menandai' atau 'berarti'. Istilah tersebut digunakan para pakar bahasa untuk menyebut bagian ilmu bahasa yang mempelajari makna. Palmer (1976) menyatakan bahwa makna tidaklah semata-mata merefleksikan realitas dunia nyata, tetapi lebih menampakkan minat atau perhatian pemakainya. Pateda (2001) menyatakan bahwa istilah makna merupakan kata dan istilah yang membingungkan, makna selalu menyatu pada tuturan kata ataupun kalimat). Dalam analisis penamaan kedai kopi di Surabaya dibutuhkanlah teori semantik leksikal yaitu makna leksikal dan makna asosiatif.

Cruse (1991) menyatakan bahwa pendekatan kontekstual mengasumsikan bahwa ciri atau "identitas" semantik unsur leksikal itu sepenuhnya dicerminkan oleh kesesuaian hubungan dengan konteks. Jadi sebuah kata memiliki 2 makna, yaitu makna referensial dan makna kontekstual. Ada beberapa jenis makna menurut Chaer (2009), yaitu leksikal, gramatikal, kontekstual, referensial, dan non 


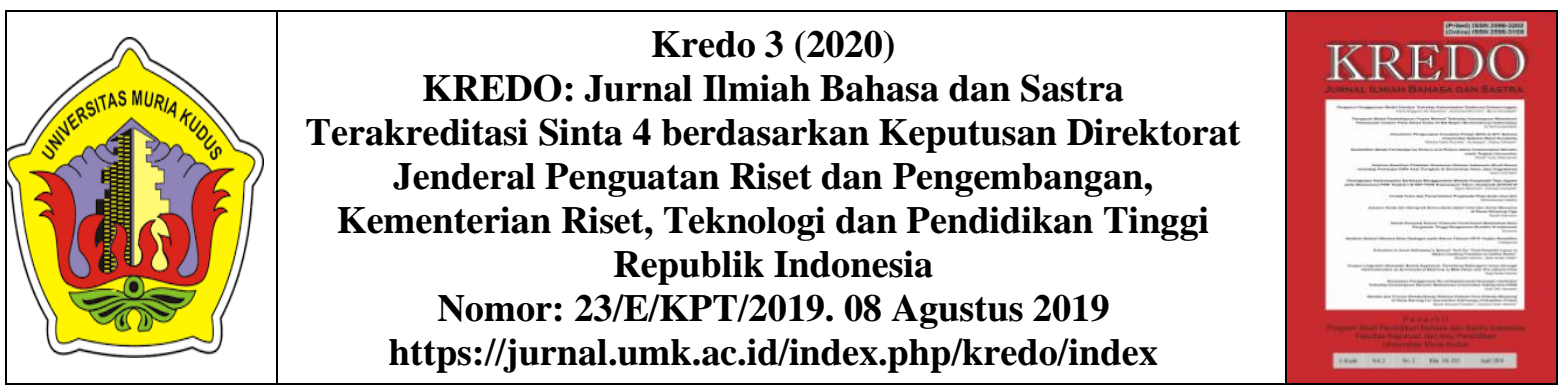

referensial, denotative, konotatif, konseptual, asosiatif, kata, istilah, idiom, serta makna peribahasa. Dalam menganalisis penamaan kedai kopi di Surabaya, peneliti menggunakan 2 jenis makna, yaitu:

1. Makna leksikal: bentuk ajektif yang diturunkan dalam bentuk nomina leksikon (kosa kata, perbendaharaan kata).

2. Makna asosiatif: makna yang dimiliki sebuah leksem atau kata berkenaan dengan adanya hubungan kata itu dengan sesuatu yang berada di luar bahasa.

Berdasarkan latar belakang yang sudah dijelaskan diatas, penulis ingin menjawab pertanyaan, bagaimanakah analisis semantik dari penamaan kedai kopi di Surabaya berdasarkan nama diri. Tujuan dari penelitian ini adalah mengkaji fenomena kebahasaan berupa penamaan kedai kopi di Surabaya yang bertema "perasaan" dari segi semantik.

Ditemukan beberapa penelitian yang relevan dengan penelitian ini adalah sebuah jurnal dari Mustofa (2012) yang meneliti nama-nama toko yang ada di Purwokerto dengan menggunakan kajian semantik dan pendekatan berupa wawancara, dari penelitian ini ditemukan fakta bahwa sebuah nama yang diberikan memiliki tujuan dan harapan dari pemilik toko. Selain itu, Rahayu (2019) meneliti penamaan tempat-tempat wisata di Kabupaten Karanganyar dengan menggunakan kajian semantik dan mengkaitkan dengan nilai historis daerah sekitar dengan menggunakan teknik wawancara, ditemukan bahwa penamaan ini adanya hubungan antara bahasa dan budaya dari masyarakat Karanganyar. Penelitian lain dari Wardoyo dan Sulaeman (2017) tentang penamaan nama-nama bangunan di Keraton
Yogyakarta, dari penelitian ini ditemukan bahwa Keraton Yogyakarta masih memegang kuat tradisi dan kepercayaan tradisional, hasil analisis ini didapat dengan jalan menggunakan pendekatan semantik dan adanya wawancara dengan abdi dalem.

Ketiga penelitian terkait diatas sama-sama menggunakan perspektif etnolinguistik yang mengerucut pada semantik untuk meneliti lebih dalam dari penamaan dari sesuatu, karena diyakini dalam memberikan nama atau melabeli sesuatu ada sebuah unsur kebudayaan didalamnya. Oleh sebab itu penggabungan pendekatan semantik dalam menguak budaya sangatlah cocok dalam meneliti proses penamaan. Untuk memperkuat hasil analisis, ketiga peneliti pun menggunakan data wawancara dalam mengkaji lebih dalam. Oleh sebab itu, penulis pun menambahkan hasil wawancara untuk memperkuat analisis.

\section{KAJIAN TEORI}

Bahasa merupakan salah satu dari tujuh unsur kebudayaan yang universal. Menurut Keraf (2004), bahasa bila ditinjau kembali dari sejarah pertumbuhan bahasa sejak awal hingga sekarang, maka fungsi bahasa dapat diturunkan dari motif pertumbuhan bahasa itu sendiri. Dasar dan motif pertumbuhan bahasa itu dalam garis besarnya dapat berupa: bahasa untuk menyatakan ekspresi, bahasa sebagai alat komunikasi, bahasa sebagai alat untuk mengadakan integrasi dan adaptasi sosial, dan bahasa sebagai alat untuk mengadakan kontrol sosial.

Bahasa pun beragam bentuknya, menurut Kridalaksana (2008) ragam bahasa adalah variasi bahasa tergantung 


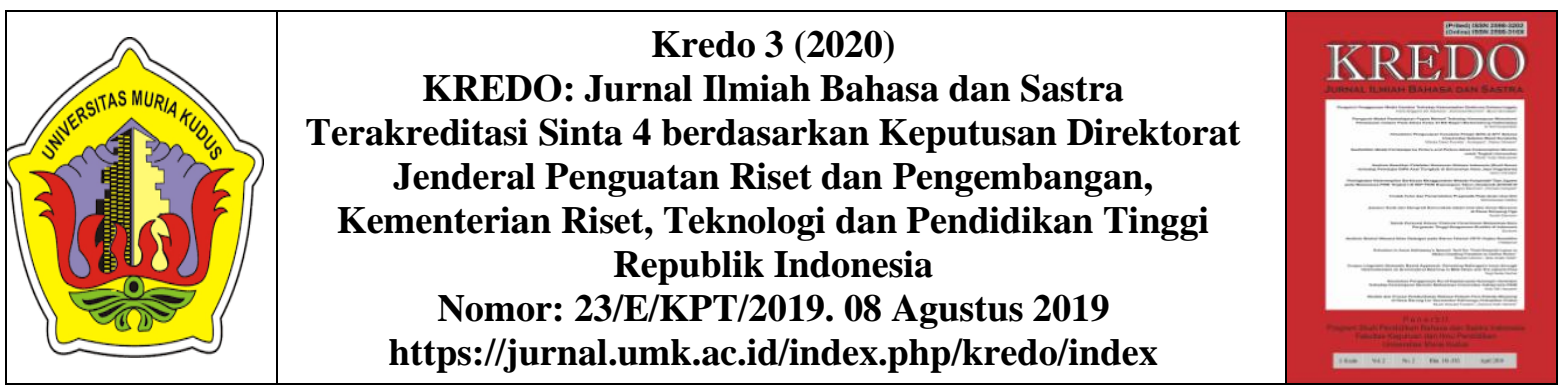

oleh pemakaian, yang berbeda-beda menurut topic yang dibicarakan, menurut hubungan pembicara, kawan bicara, dan orang yang dibicarakan, serta medium pembicaranya. Ragam bahasa berdasarkan pada sarananya terbagi atas dua jenis yaitu: ragam bahasa lisan dan ragam bahasa tulis.

Pada penelitian ini, penulis ingin mengkaji ragam bahasa tulis, yaitu variasi bahasa yang digunakan dengan medium tulisan. Dalam menjembatani antara bahasa dan budaya dalam fenomena penamaan dibutuhkan sebuah ilmu kebahasaan yang juga berhubungan dengan budaya. Hymes (dalam Wardhaugh (2006) menjelaskan bahwa bahasa dan etnografi saling berhubungan. Etnografi sendiri menjelaskan deskripsi dari struktur sosial, aktifitas masyarakat, sumber material dan simbolik yang menggambarkan kondisi masyarakat tertentu. Sedangkan bahasa dalam hal ini menjadi sumber penting untuk diamati, terutama bagaimana bahasa digunakan dalam aktifitas kemasyarakatan, agama, lagu atau nyanyian. Hal inilah yang melatarbelakangi munculnya kajian etnolinguistik.

Menurut

Abdullah (2013), etnolinguistik merupakan sebuah ilmu kebahasaan yang menitikberatkan pada dimensi bahasa seperti sosial dan budaya. Selain itu menurut Haugen (dalam Aron 2007) menyatakan bahwa etnolingustik bisa diartikan sebagai salah satu kajian dari beberapa kajian ekologi bahasa yang sudah mapan. Disini Haugen menyebutkan bahwa etnolinguistik ini membedah dan memilah-milah penggunaan bahasa, cara dan pola pikir dalam katian dengan pola penggunaan bahasa, cara dan pola pikir dala kaitan dengan pola penggunaan bahasa, bahasa-bahasa ritual, dan kreasi wacana.

Kata "budaya" sendiri didalam Kamus Besar Bahasa Indonesia (KBBI) (2016) memiliki arti: 1) pikiran: akal budi, 2) adat istiadat, 3) sesuatu mengenai kebudayaan yang sudah berkembang (beradab, maju), 4) sesuatu yang sudah menjadi kebiasaan yang sukar diubah. Sedangkan "kebudayaan", memiliki makna: 1) hasil kegiatan dan penciptaan batin (akal budi) manusia seperti kepercayaan, kesenian, dan adat istiadat, 2) keseluruhan pengetahuan manusia sebagai makhluk sosial yang digunakan untuk memahami lingkungan serta pengalamannya dan yang menjadi pedoman tingkah lakunya. Dari makna kata budaya dan kebudayaan menurut Kamus Besar Bahasa Indonesia (KBBI) (2016) dapat dikatakan bahwa budaya merupakan sebuah kebiasaan atau adat istiadat yang terbentuk dari pikiran, akal budi, pengetahuan, perilaku serta keyakinan yang berkembang pada masyarakat dan menjadi pedoman dalam kehidupan mereka untuk menjadi manusia yang maju dan beradab.

Selain berhubungan dengan budaya dan kebudayaan, ditambahkan pula oleh Abdullah (2014), bahwa orientasi terpenting dalam kajian etnolinguistik sangat membutuhkan pemahaman tentang semantik leksikal.

Palmer (dalam Aminuddin, 2008) menyatakan bahwa semantik berasal dari bahasa Yunani, mengandung makna to signify (memaknai). Sebagai istilah teknis, semantik memiliki istilah pengertian studi tentang makna. Dengan anggapan bahwa makna menjadi bagian dari bahasa, jadi semantic adalah bagian dari linguistik. Lalu Verhaar (2001) menyatakan bahwa semantic merupakan cabang linguistik yang membahas arti 


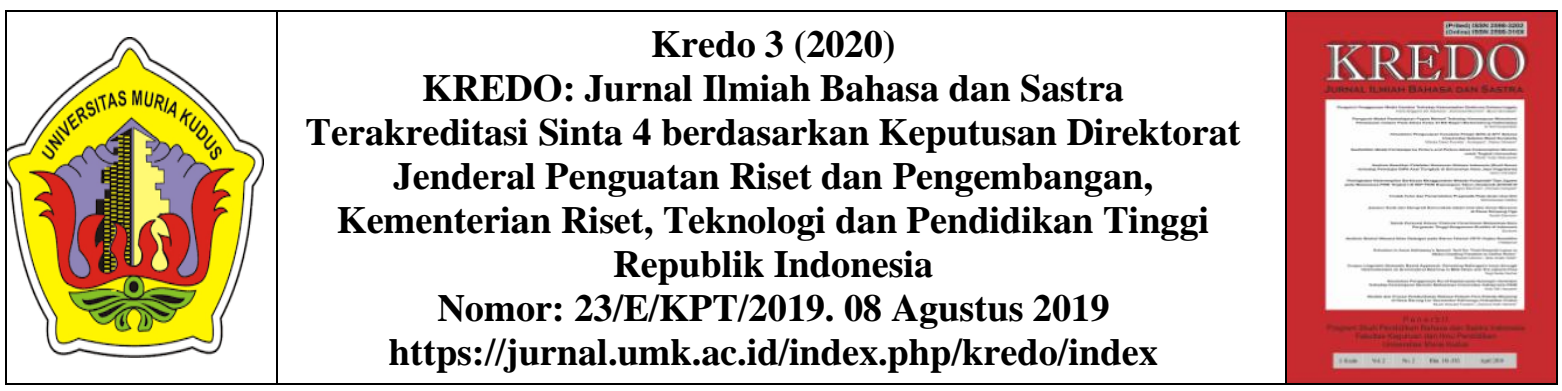

atau makna. Dari beberapa pengertian tersebut, dapat disimpulkan jika semantic adalah bagian dari ilmu linguistik yang mengkaji tentang makna atau arti, atau sederhananya adalah hubungan antara bentu-bentuk linguistik dengan entitas di dunia. Bisa dikatakan hubungan kata-kata dengan sesuatu secara harfiah.

Kridalaksana (2008) menyatakan bahwa makna adalah hubungan dalam arti kesepadanan atau ketidaksepadanan antara bahasa dan alam diluar bahasa, atau antara ujaran dan semua hal yang ditunjuknya. Lyons (dalam Djajasudarma 2009) menyebutkan bahwa mengkaji atau memberikan makna suatu kata ialah memahami kajian kata tersebut yang berkenaan dengan hubungan-hubungan makna yang membuatkata tersebut berbeda dari katakata lain. Dapat disimpulkan bahwa makna adalah sebuah hubungan dalam arti kesepadanan atau ketidaksepadanan antara bahasa dan aspek di luar bahasa, atau antara ujaran dan semua hal yang ditunjuknya.

Cruse (1991) menyatakan bahwa sebuah kata memiliki 2 makna, yaitu makna referensial dan makna kontekstual. Ada beberapa jenis makna menurut Chaer (2009), yaitu leksikal, gramatikal, kontekstual, referensial, dan non referensial, denotative, konotatif, konseptual, asosiatif, kata, istilah, idiom, serta makna peribahasa. Dalam menganalisis penamaan kedai kopi di Surabaya, peneliti menggunakan 2 jenis makna, yaitu:

1. Makna leksikal: bentuk ajektif yang diturunkan dalam bentuk nomina leksikon (kosa kata, perbendaharaan kata).

2. Makna asosiatif: makna yang dimiliki sebuah leksem atau kata berkenaan dengan adanya hubungan kata itu dengan sesuatu yang berada di luar bahasa.

\section{METODE PENELITIAN}

Penelitian ini menggunakan pendekatan secara teoritis yang merupakan pendekatan etnolinguistik, dan pendekatan metodologis yang berupa pendekatan deskriptif kualitatif. Lokasi yang dipilih dalam melaksanakan penelitian ini yaitu Surabaya, dan pada penelitian ini, penulis menggunakan sumber data nama-nama kedai kopi di Surabaya yang sudah diklasifikasikan kedalam kategori kedai kopi yang bertemakan "perasaan". Disini peneliti ingin menjawab pertanyaan "bagaimana penamaan terbentuk dengan analisis semantik?". Dalam menjawab pertanyaan ini, peneliti mengkaji Sembilan nama kedai kopi yang ada di Surabaya dan mengkerucutkan pada tema "perasaan".

Ditemukan sepuluh nama kedai kopi yang akan dikaji lebih lanjut, yaitu Janji Jiwa, Lain Hati, Kopi Kenangan, Kopi Kangen, Pelipur Lara, Awal Cerita Kopi, Kopi Teman Baik, Kopi Teman Mikir, Kopi Koko Nakal, dan Titik Koma Coffee. Di penelitian ini, penulis mengkaji dari segi semantik untuk mengungkap makna dengan menggunakan dua jenis makna menurut Chaer (2009) yaitu: makna leksikal dan makna asosiatif.

Langkah-langkah yang dilakukan oleh penulis adalah:

1. Menentukan makna leksikal dari nama kedai kopi yang telah dipilih, yaitu: Janji Jiwa, Lain Hati, Kopi Kenangan, Kopi Kangen, Pelipur Lara, Awal Cerita Kopi, Kopi Teman Baik, Kopi Teman Mikir, 


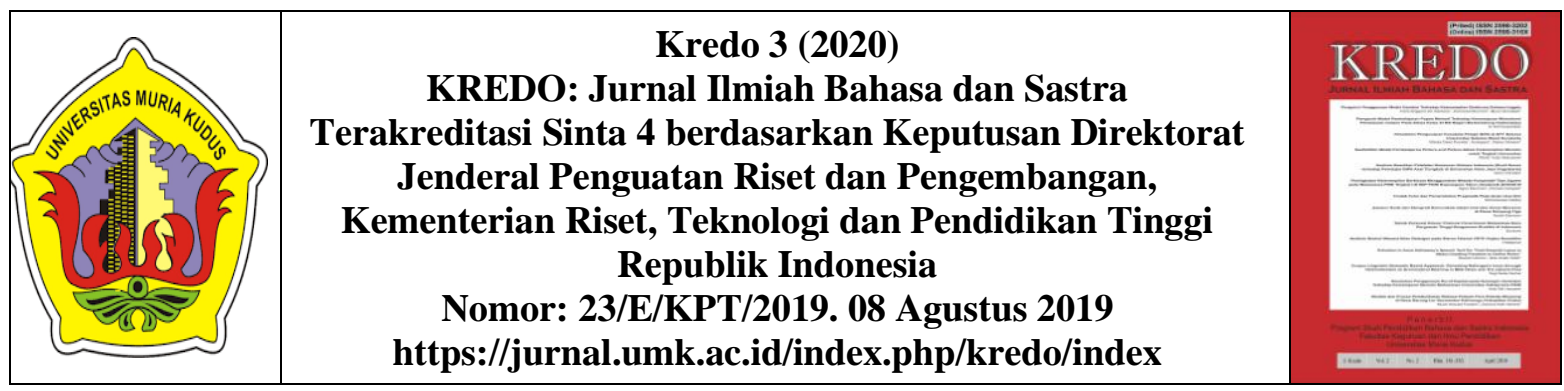

Kopi Koko Nakal, dan Titik Koma Coffee. Contoh: apakah termasuk nomina, adjektiva ataukah verba.

2. Lalu, melihat arti kata yang sesungguhnya dari kedai kopi yang sudah terpilih pada Kamus Besar Bahasa Indonesia (KBBI) (2016).

3. Terakhir adalah dalam menunjang penelitian, penulis pun menambahkan hasil wawancara dari pemilik kedai kopi untuk mengetahui latar belakang penamaan kedai kopi di Surabaya. Penambahan hasil wawancara bermanfaat untuk mengetahui apakah makna makna dalam penamaan ini berhubungan dengan latar belakang dari keinginan dari pemiliknya.

\section{HASIL DAN PEMBAHASAN}

\section{Analisis Semantik Nama-Nama Kedai Kopi di Surabaya}

Peneliti ingin mengkaji proses penamaan dari kedai kopi yang ada di Surabaya dengan melihat makna leksikal dan makna asosiatif yang digagas oleh Chaer (2009) untuk melihat makna yang terkandung didalamnya. Ditemukan sembilan kedai kopi yang menggunakan tema "perasaan" sebagai nama. Kesepuluh kedai kopi di Surabaya ini adalah Janji Jiwa, Lain Hati, Kopi Kenangan, Kopi Kangen, Pelipur Lara, Awal Cerita Kopi, Kopi Teman Baik, Kopi Teman Mikir, Kopi Koko Nakal, dan Titik Koma Coffee. Dalam penelitian ini, peneliti menambahkan hasil wawancara dengan para pemilik kedai kopi agar hasil analisis lebih kuat.

\section{(1) Janji Jiwa}

Kedai kopi Janji Jiwa merupakan salah satu kedai kopi di Surabaya yang menggunakan tema "perasaan". Jika dilihat dari sisi makna leksikal, "janji" adalah verba (kata kerja), dan "jiwa" adalah nomina (kata benda). Disini, verba (kata kerja) merupakan kelas kata yang menyatakan suatu tindakan, keberadaan, pengalaman, atau pengertian dinamis lainnya. Kata kerja umumnya menjadi predikat dalam suatu frasa atau kalimat. Berdasarkan objeknya, kata kerja dibagi menjadi dua: kata kerja transitif (kata kerja yang membutuhkan objek) dan kata kerja intransitive (kata kerja yang tidak membutuhkan objek). Pada konteks "janji jiwa”, ini merupakan kata kerja transitif karena disini terdapat verba dan nomina yang saling berkaitan yang menjelaskan "janji" dari sebuah "jiwa".

Makna asosiatif dari "janji jiwa" yang dilihat dari Kamus Besar Bahasa Indonesia (KBBI) (2016), “janji” memiliki makna: 1) ucapan yang menyatakan kesediaan dan kesanggupan untuk berbuat (seperti hendak member, menolong, datang, bertemu), 2) persetujuan antara dua pihak (masingmasing menyatakan kesediaan dan kesanggupan untuk berbuat atau tidak berbuat sesuatu), 3) syarat; ketentuan (yang harus dipenuhi), 4) penundaan waktu; penangguhan, 5)batas waktu (hidup); adat harus dijalankan. Kata "jiwa", menurut Kamus Besar Bahasa Indonesia (KBBI) (2016) memiliki makna: 1) roh manusia; nyawa, 2) seluruh kehidupan batin manusia (yang terjadi dari perasaan, pikiran, anganangan), 3) sesuatu atau orang yang utama dan menjadi sumber tenaga dan semnagat, 4) isi (maksud) yang sebenarnya; arti (maksud) yang tersirat (dalam perkataan, perjanjian, dan sebagainya), 5) buah hati; kekasih, 6) orang (dalam perhitungan penduduk), 7) 


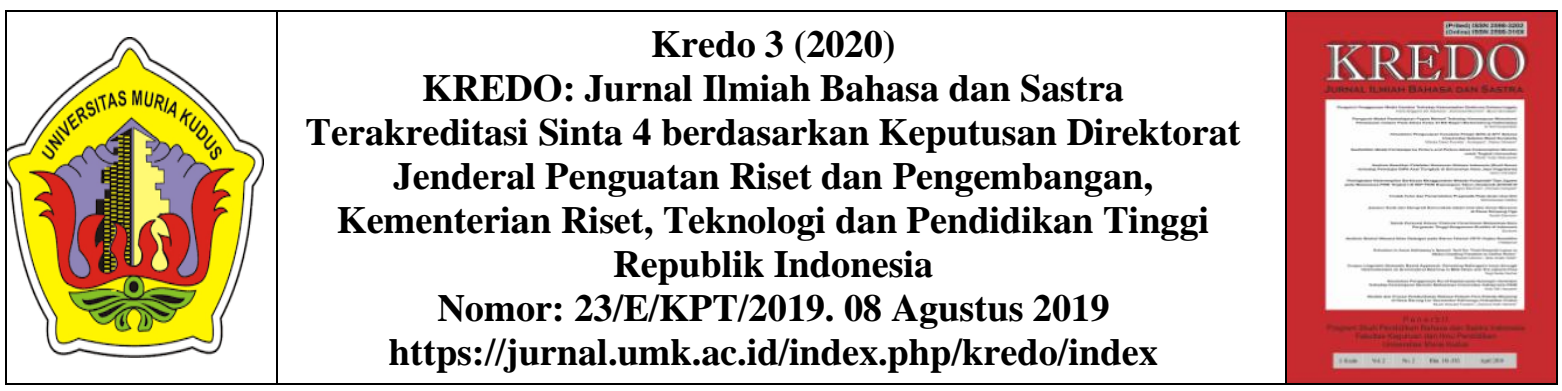

daya hidup orang atau makhluk hidup lainnya. Jika digabungkan "janji jiwa" memiliki makna sebuah kesediaan atau persetujuan dari yang tersayang atau kekasih.

Hasil wawancara dengan pemilik menunjukkan bahwa memang nama "janji jiwa" ini sengaja untuk memikat pelanggan. Pemilik menjelaskan bahwa "janji jiwa" memiliki banyak arti dan memang sengaja dipilih agar para penggemar kopi ini bisa menginterpretasikan "janji jiwa" sesuai dengan background knowledge (pengeteahuan dasar) masing-masing. Ada yang menghubungkan dengan cinta, yang berarti sebuah kesanggupan dari seorang kekasih kepada pasangannya yang sedang dimabuk cinta. Jadi sang pemilik ingin penikmat/pelanggannya memiliki interpretasi sendiri-sendiri dalam mengartikan "janji jiwa". Akan tetapi arti yang ingin diusung oleh Billy Kurniawan (sang pemilik) sebenarnya adalah seluruh staff kedai kopi ini berjanji dengan segenap hati untuk memberikan kopi dan minuman yang terbaik bagi para pelanggan.

\section{(2) Lain Hati}

Selain kedai kopi Janji Jiwa, adapula kedai kopi yang menggunakan tema perasaan yaitu kedai kopi Lain Hati. Jika dilihat dari sisi makna leksikal "lain" adalah adjektiva (kata sifat), dan "hati" adalah nomina (kata benda). Disini, kata sifat atau adjektiva adalah kelas kata yang berfungsi mengubah kata benda (nomina), biasanya dengan menjelaskannya atau membuatnya menjadi lebih spesifik. Dalam konteks ini "lain" menjelaskan keadaan dari sebuah "hati"

Makna asosiatif dari "lain hati" berdasarkan pada Kamus Besar Bahasa
Indonesia (KBBI) (2016), "lain" berarti: 1) asing, beda, tidak sama (halnya, rupanya, dan sebagainya), 2) kecuali; tidak termasuk (dalam hitungan, golongan, dan sebagainya), 3) berselisih; berbeda. Lalu kata "hati" menurut Kamus Besar Bahasa Indonesia (KKBI) (2016) memiliki arti: 1) organ badan yang berwarna kemerah-merahan di bagian kanan atas rongga perut, gunanya untuk mengambil sari-sari makanan di dalam darah dan menghasilkan empedu, 2) daging dari hati sebagai baan makanan (terutama hati dari binatang sembelihan), 3) jantung, 4) sesuatu yang ada di dalam tubuh manusia yang dianggap sebagai tempat segala perasaan batin dan tempat menyimpan pengertian (perasaan dan sebagainya), 5) apa yang terasa dalam batin, 6) sifat (tabiat) batin manusia, 7) bagian yang di dalam sekali (tentang buah, batang, tumbuhan, dan sebagainya). Jika digabungkan, "lain hati" memiliki makna tidak sama perasaannya atau berbeda rasa batin.

Jika dilihat dari hasil wawancara dengan brand ambassador dari kedai kopi Lain Hati, kata "lain hati" ini memang ini menunjukkan kalau kedai ini memang berbeda daripada yang lain. Kata "hati" ini dpilih karena memang mengikuti tren kedai kopi yang muncul di Surabaya dengan menggunakan tema "perasaan", kata "hati" sangat erat hubungannya denga perasaan. Ririn Ekawati selaku brand ambassador mengungkapkan bahwa konsep menu yang ada di kedai ini berbeda dengan kopi-kopi yang lain. Oleh karena itu nama Lain Hati dirasa paling cocok untuk mewakili konsep dari kedai kopi ini. 


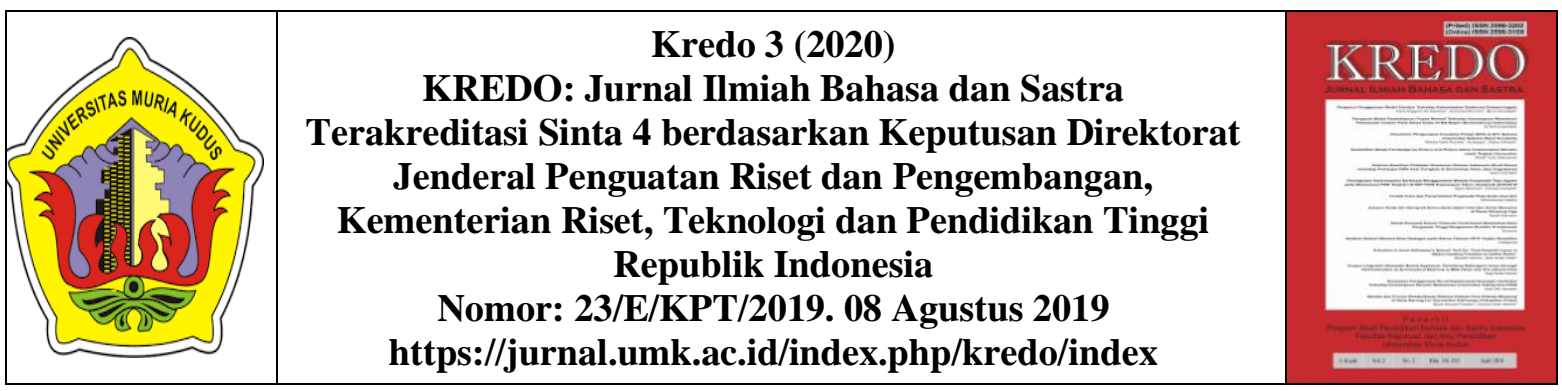

\section{(3) Kopi Kenangan}

Ditemukan satu lagi kedai kopi yang menggunakan tema "perasaan" yaitu Kopi Kenangan. Jika dilihat dari sisi makna leksikal "kenangan" adalah sebuah nomina (kata benda).

Makna asosiatif dari kata "kenangan" jika dilihat dari Kamus Besar Bahasa Indonesia (KBBI) (2016), "kenangan" memiliki pengertian: 1) sesuatu yang membekas dalam ingatan; kesan, 2) kesan dalam ingatan (pikiran). Jadi secara umum "kenangan" memiliki arti sesuatu yang membekas dalam ingatan atau dapat diartikan sebagai momen yang tidak terlupakan.

Jika dilihat berdasarkan hasil wawancara dengan pemilik kedai Kopi Kenangan, kata "kenangan" dipilih dengan alasan bahwa kata ini memiliki arti yang dalam dan terlihat mahal. Walaupun mengusung tema "mahal", Edward Tirtanata selaku pemilik menjamin bahwa kopinya yang rasanya tidak kalah dengan gerai-gerai internasional ini tetaplah terjangkau dan tidaklah mahal. Dia pun menambahkan bahwa Kopi Kenangan ini membuat susah moveon, karena rasanya yang pasti akan membekas dan sulit dilupakan oleh penikmatnya. Dan nama "Kenangan" ini sangat bisa mewakili konsep yang ingin diusung oleh pemiliknya yaitu membekas sehingga membuat penikmatnya mengenang dari rasa kopi ini. Serta kata "kenangan" ini sangat kental penggunaannya dalam menggambarkan perasaan.

\section{(4) Kopi Kangen}

Kopi Kangen merupakan salah satu kedai kopi di Surabaya yang juga menggunakan tema "perasaan" dalam memilih nama kedai kopi. Jika dilihat dari makana leksikal "kangen" merupakan adjektiva (kata sifat) atau bisa juga sebagai nomina (kata benda). Untuk konteks kali ini dalam penamaan "kangen" berfungsi sebagai kata sifat yang berubah menjadi kata benda diri (proper nouns).

Makna asosiatif dari kata "kangen" jika dilihat dari Kamus Besar Bahasa Indonesia (KBBI) (2016), "kangen" memiliki arti ingin sekali bertemu; rindu. Jadi, "kangen" memiliki arti rindu dan ingin berjumpa.

Jika dilihat dari hasil wawancara dengan pemilik kedai Kopi Kangen menunjukkan bahwa pemilihan kata "kangen" mempunyai filosofi yang ingin dikaitkan dengan kedai kopi ini. Kata "kangen" ini memanglah memiliki tujuan bahwa penikmat kopi pasti akan rindu serta ingin berjumpa (merasakan lagi) dan ingin meminum kopi ini lagi jika sudah pernah mencicipinya. Kata "kangen" pun sangat sering digunakan dalam menggambarkan sebuah perasaan.

\section{(5) Pelipur Lara}

Pelipur Lara adalah kedai kopi di Surabaya yang memakai tema "perasaan". Jika dilihat dari makna leksikal, "pelipur" merupakan adjektiva (kata sifat), dan "lara" adalah nomina (kata benda). Disini, kata sifat atau adjektiva adalah kelas kata yang berfungsi mengubah kata benda (nomina), biasanya dengan menjelaskannya atau membuatnya menjadi lebih spesifik. Dalam konteks ini menjelaskana bahwa "lara" menjelaskan sebuah "pelipur".

Makna asosiatif dari "pelipur lara" jika dilihat Kamus Besar Bahasa Indonesia (KBBI) (2016), "pelipur" mempunyai arti penghibur. Sedangkan "lara" pada Kamus Besar Bahasa Indonesia (KBBI) (2016) memiliki arti 


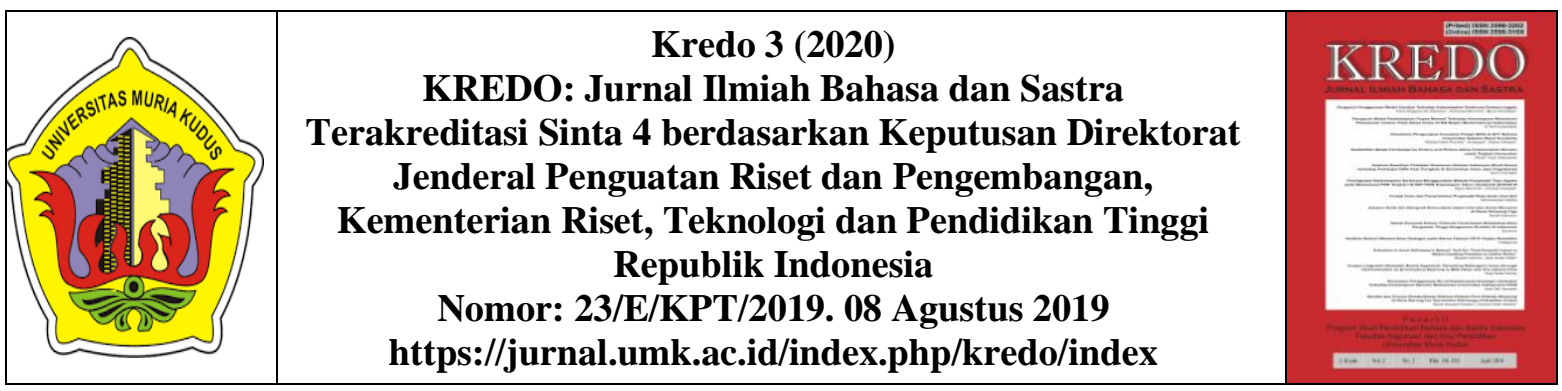

1) sedih; susah hati, 2) sakit; sakit hati karena malu. Bisa dikatakan jika "pelipur lara" mempunyai arti penghibur dari rasa sedih atau sakit hati.

Menurut pemilik kedai kopi Pelipur Lara, memang kedai kopi ini dikonsep untuk penikmat kopi yang sedang sedih, galau dan sakit hati. Menurutnya, dengan meminum kopi yang enak dari kedai kopi Pelipur Lara dapat sedikit mengurangi rasa sedih, galau, dan sakit hati. Jadi pemilihan nama kedai kopi ini sangat tepat untuk konsep yang ingin diusung oleh pemiliknya. Dan kata "lara" sendiri merupakan penggambaran dari sebuah perasaan.

\section{(6) Awal Cerita Kopi}

Salah satu kedai kopi yang masuk kedalam list kedai kopi di Surabaya dengan tema "perasaan". Jika diliat dari segi makna leksikal, "awal" merupakan adjektiva (kata sifat), dan "cerita" merupakan nomina (kata benda). Disini, kata sifat atau adjektiva adalah kelas kata yang berfungsi mengubah kata benda (nomina), biasanya dengan menjelaskannya atau membuatnya menjadi lebih spesifik. Dalam konteks ini, "awal" menjelaskan sebuah "cerita".

Melihat dari makna asosiatif, kata "awal" dalam Kamus Besar Bahasa Indonesia (KBBI) (2016) mempunyai arti 1) mula-mula (sekali), 2) permulaan; yang mula-mula, 3) jauh sebelum waktu yang ditentukan. Kata "cerita" menurut Kamus Besar Bahasa Indonesia (KBBI) (2016) mempunyai arti 1) tuturan yang membentangkan bagaimana terjadinya suatu hal (peristiwa, kejadian, dan sebagainya), 2) karangan yang menuturkan perbuatan, pengalaman, atau penderitaan orang; kejadian dan sebagainya (baik yang sungguh-sungguh terjadi maupun yang hanya rekaan belaka), 3) lakon yang diwujudkan atau dipertunjukkan dalam gambaran hidup (sandiwara, wayang, dan sebagainya), 4) omong kosong; dongengan (yang tidak benar); omongan. Secara garis besar, bisa dikatakan bahwa "awal cerita" mempunyai arti permulaan dari sebuah kejadian atau peristiwa.

Berdasarkan hasil wawancara dengan pemilik kedai kopi adalah kedai ini memang namanya mewakili misinya, yaitu untuk menjawab keinginan dari teman-teman mahasiswa yang ingin mengawali harinya dengan meminum kopi di pagi hari. Ini dikarenakan jarangnya ada kedai kopi grinder yang buka sejak pagi. Dan pemilihan nama "awal cerita" dirasa sangat mewakili misi dan harapan dari pemiliknya.

\section{(7) Kopi Teman Baik}

Kopi Teman Baik adalah salah satu kedai kopi yang menggunakan tema "perasaan". Jika dilihat dari segi makna leksikal, "teman" merupakan nomina (kata benda), dan "baik" merupakan kata sifat. Disini, kata sifat atau adjektiva adalah kelas kata yang berfungsi mengubah kata benda (nomina), biasanya dengan menjelaskannya atau membuatnya menjadi lebih spesifik. Dalam konteks ini "baik" menjelaskan dari seorang "teman".

Makna asosiatif jika dilihat dari Kamus Besar Bahasa Indonesia (KBBI) (2016), "teman" memiliki arti 1) kawan; sahabat, 2) orang yang bersama-sama bekerja (berbuat, berjalan); lawan (bercakap-cakap), 3) yang menjadi pelengkap (pasangan) atau yang dipakai (dimakan dan sebagainya) bersamasama. Kata "baik" jika dilihat dari sisi maknanya menurut Kamus Besar Bahasa Indonesia (KBBI) (2016) mempunyai arti 1) elok; patut; teratur (apik, rapi, 


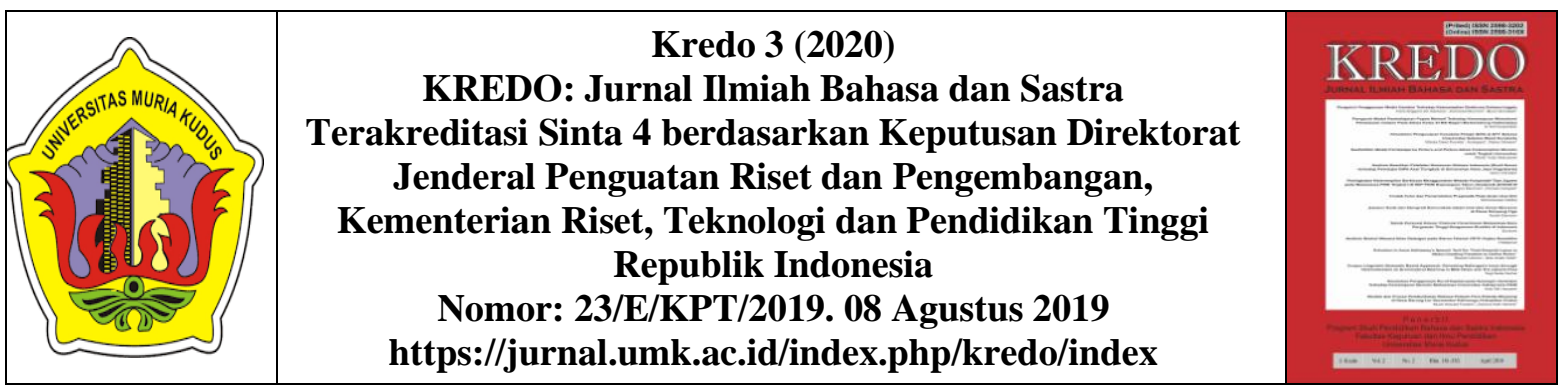

tidak ada celanya, dan sebagainya), 2) mujur; beruntung (tentang nasib); menguntungkan (tentang kedudukan dan sebagainya), 3) berguna; manjur (tentang obat dan sebagainya), 4) tidak jahat (tentang kelakuan, budi pekerti, keturunan, dan sebagainya); jujur, 5) sembuh; pulih (tentang luka, barang yang rusak, dan sebagainya), 6) selamat (tidak kurang suatu apa), 7) selayaknya, sepatutnya, 8) ya (untuk menyatakan setuju), 9) kebaikan; kebajikan. Secara garis besar, "teman baik" memilik arti sahabat yang tidaak ada celanya.

Menurut hasil wawancara dengan pemilik Kopi Teman Baik, pemilihan namanya tidak terlepas dari keinginan pemilik untuk menjadikan kopi sebagai teman yang baik dari penikmatnya. Disini, pemilik ingin membuat kopi menjadi seorang sahabat yang bisa diandalkan, kawan yang bisa selalu menemani di segala kegiatan dan segala perasaan yang sedang dirasakan, seperti bahagia, sedih, dan lain-lain. Hasil wawancara ini berbanding lurus dengan makna asosiatif yang telah ditemukan.

\section{(8) Kopi Teman Mikir}

Salah satu kedai kopi di Surabaya yang menggunakan tema "perasaan" adalah Kopi Teman Mikir. Jika dilihat dari segi makna leksikal, "teman" merupakan nomina (kata benda), dan "mikir" merupakan verba (kata kerja). Disini, verba (kata kerja) merupakan kelas kata yang menyatakan suatu tindakan, keberadaan, pengalaman, atau pengertian dinamis lainnya. Kata kerja umumnya menjadi predikat dalam suatu frasa atau kalimat. Verba "mikir" disini tidak membutuhkan objek karena dalam konteks penamaan, frasa terbentuk menjadi kata benda nama diri (proper nouns). Dalam konteks ini "mikir" menjelaskan seorang "teman".

Makna asosiatif jika dilihat dari Kamus Besar Bahasa Indonesia (KBBI) (2016), "teman" memiliki arti 1) kawan; sahabat, 2) orang yang bersama-sama bekerja (berbuat, berjalan); lawan (bercakap-cakap), 3) yang menjadi pelengkap (pasangan) atau yang dipakai (dimakan dan sebagainya) bersamasama. Kata "mikir" tidak ditemukan pada Kamus Besar Bahasa Indonesia (KBBI) (2016) karena "mikir" bukanlah kata baku. Disini "pikir" adalah kata baku yang memiliki arti: 1) akal budi; ingatan; amgan-angan, 2) kata dalam hati; pendapat (pertimbangan); kira. Secara garis besar "teman mikir" mempunyai pengertian orang yang bersama-sama berangan-angan, mempertimbangkan dan berpendapat dalam hati.

Menurut hasil wawancara dengan pemiliknya, Kopi Teman Mikir ini adalah kopi dari masa depan yang memudahkan penikmatnya yaitu menawarkan sistem bebas antri, pemesanan yang mudah dengan menggunakan aplikasi. Jadi disini pemilik mengajak penikmatnya untuk bersama-sama menikmati kopi dengan mudah tanpa harus berangan-angan. Jadi langsung pesan saja di aplikasi dan kopi siap sedia tanpa pikir panjang.

\section{(9) Kopi Koko Nakal}

Kopi Koko Nakal merupakan salah satu kedai kopi di Surabaya yang memakai tema "perasaan". Dilihat dari segi makna leksikal, "koko" merupakan nomina (kata benda), dan "nakal" merupakan adjektiva (kata sifat). Disini, kata sifat atau adjektiva adalah kelas kata yang berfungsi mengubah kata benda (nomina), biasanya dengan 


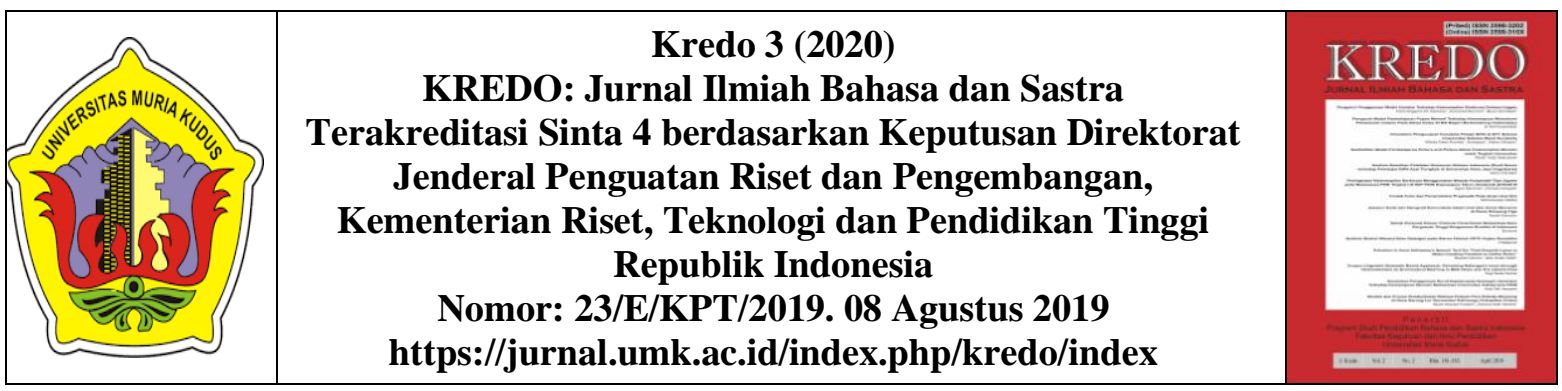

menjelaskannya atau membuatnya menjadi lebih spesifik. Dalam konteks ini, kata "nakal" menjelaskan secara spesifik bahwa yang "nakal" adalah "koko".

Makna asosiatif jika dilihat dari Kamus Besar Bahasa Indonesia (KBBI) (2016), kata "koko" tidak ditemukan di KBBI karena bukan merupakan kata baku. "Koko" mempunyai arti kakak laki-laki yang biasanya digunakan oleh orang Tionghoa di Surabaya. Kata "nakal" dalam Kamus Besar Bahasa Indonesia (KBBI) (2016) mempunyai arti 1) suka berbuat kurang baik (tidak menurut, mengganggu, dan sebagainya, terutama bagi anak-anak), 2) buruk kelakuan (lacur dan sebagainya). Jika disimpulkan "koko nakal" mempunyai arti kakak lelaki (Tionghoa) yang suka berbuat kurang baik.

Menurut hasil wawancara, kedai kopi ini dimiliki oleh tiga lelaki Tionghoa yang memang sesuai namanya disebut "Koko". Mereka mengaku bahwa mereka dipertemukan oleh kopi dan mempunyai hobi yang sama yaitu minum kopi. Berangkat dari kesamaan hobi dan kesenangan, mereka memutuskan untuk membuka kedai kopi dengan konsep yang unik. Mereka mengatakan bahwa kopinya tidak dikonsep untuk minum ditempat, jadi kopi ini sangat praktis dan bisa dibawa kemana-mana sembari beraktifitas. Untuk deskripsi "nakal", ini lebih pada penggambaran dari nama-nama kopi dalam menu yang ditawarkan, seperti: kopi susu mantan (mantap tenan), kopi mantab kelam (kopi hitam), es coklat selingkuh, dan bahkan susu janda (taro). Pemilihan nama yang unik pada menu, membuat pemiliknya menggunakan kata "nakal" dalam penamaan kedai kopinya. Dapat disimpulkan bahwa sebuah nama dan label merupakan sebuah identitas yang ingin digambarkan oleh pemberi nama.

\section{(10) Titik Koma Coffee}

Salah satu kedai kopi di kota Surabaya yang menggunakan tema "perasaan" adalah Titik Koma Coffee. Jika dilihat dari segi makna leksikal, "titik koma" merupakan sebuah nomina (kata benda).

Jika melihat makna asosiatif dan menilik dari Kamus Besar Bahasa Indonesia (KBBI) (2016), kata "titik koma" mempunyai kata dasar "titik" pada KBBI. Kata "titik" mempunyai arti: 1) noktah (pada huruf, tanda, tanda baca, dan sebagainya). -koma: tanda baca berupa titik dan koma (;) untuk menandai bagian kalimat yang sejenis dan setara, juga untuk memisahkan kalimat yang setara dalam kalimat majemuk sebagai pengganti kata penghubung. Untuk kata "koma" sendiri, didalam Kamus Besar Bahasa Indonesia (KBBI) (2016) mempunyai arti: tanda baca (,) yang dipakai untuk memisahkan unsur dalam suatu perincian, memisahkan nama orang dari gelar akademik yang mengiringinya, memisahkan anak kalimat yang mendahului induk kalimat, mengapit keterangan tambahan atau keterangan aposisi dalam kalimat, dan sebagainya.

Menurut hasil wawancara dengan pemilik kedai kopi ini, nama Titik Koma mempunyai arti "ngopi" tanpa henti, setelah titik ada koma lagi, titik lagi dan koma lagi. Jadi makna yang ingin disampaikan oleh sang pemilik bukanlah frasa "titik koma", karena frasa ini memiliki arti: kata penghubung yang berfungsi untuk memisahkan kalimat setara. Makna "titik" sebagai tanda baca berupa noktah dan mengindikasikan 


Kredo 3 (2020)
KREDO: Jurnal Ilmiah Bahasa dan Sastra
Terakreditasi Sinta 4 berdasarkan Keputusan Direktorat
Jenderal Penguatan Riset dan Pengembangan,
Kementerian Riset, Teknologi dan Pendidikan Tinggi
Republik Indonesia
Nomor: 23/E/KPT/2019. 08 Agustus 2019
https://jurnal.umk.ac.id/index.php/kredo/index

selesainya suatu kalimat, sedangkan "koma" mempunyai arti tanda baca yang memisahkan suatu perincian dan dalam pembacaannya akan ada jeda. Jadi memang makna dan keinginan dari sang pemilik kedai kopi berbanding lurus.

Data diatas merupakan hasil dari kajian penamaan sepuluh kedai kopi di kota Surabaya yang difokuskan pada kedai kopi dengan tema "perasaan". Karena ini merupakan fenomena yang terbilang baru di Surabaya, karena biasanya kedai kopi memakai nama yang memang berhubungan dengan kopi dan variannya, atau memakai nama-nama asing, atau malah memakai nama daerah. Jika dilihat dari makna leksikalnya, sesuai dengan yang diutarakan Sibarani (2006) dalam penamaan akan ada nama yang lebih spesifik yaitu proper name, yang membuat kata benda, kata kerja, maupun kata benda menjadi sebuah kata benda nama diri (proper nouns). Serta secara asosiatif dan dilihat dari Kamus Besar Bahasa Indonesia (KBBI) (2016), proper name memang berhubungan dengan budaya. Dalam konteks kali ini, sebuah budaya merupakan background knowledge dari para pemilik kedai kopi. Nama-nama yang diberikan oleh pemilik dalam menamai kedai kopi merupakan hasil pemikiran dari pemiliknya dan memang sebuah nama berbanding lurus dengan harapan dari pemilik dalam memberi nama.

\section{SIMPULAN}

Dari hasil penemuan pada kesepuluh kedai kopi diatas, dapat disimpulkan bahwa pemilihan nama memang berbanding lurus dengan harapan atau keinginan dari seseorang dalam memberikan nama. Ini bisa dilihat dara ditemukannya makna leksikal dan asosiatif yang benar-benar berbanding lurus dengan harapan dari para pemilik kedai kopi yang didapat dari hasil wawancara. Serta, terlihat juga bahwa kekuatan sebuah makna bisa terpancar dari kesamaan antara makna sesungguhnya dari nama-nama kedai kopi yang dipilih oleh pemiliknya dengan harapan yang dimiliki oleh pemilik. Dari semua nama kedai kopi yang bertema "perasaan" ini selalu membawa kesan positif dan ingin member energi yang baik untuk para penikmatnya, walaupun dengan misi dan konsep yang berbeda. Penamaan kedai kopi sebagai simbol harapan dari pemiliknya menjadi hal yang menarik untuk dikaji secara mendalam, makna kultural berupa "perasaan" menjadi tema besar dalam pemberian nama kedai kopi di Surabaya. Pengaruh tren dan perkembangan jaman adalah pengaruh terbesar pada fenomena ini.

Penelitian ini diharapkan adanya manfaat yang besar untuk pembacanya. Manfaat dari penelitian ini adalah adanya manfaat teoretis dan praktis. Manfaat teoretis dari penelitian ini adalah untuk mengetahui klasifikasi penggunaan bahasa khususnya dalam ilmu linguistik dengan menggunakan kajian etnolinguistik yang mengerucut pada semantik yang memang fungsinya diharapkan menganalisis sistem penamaan kedai kopi di Surabaya, khususnya yang mempunyai tema "perasaan", serta untuk menambah pengetahuan teori tentang pemakaian bahasa tulis. Sedangkan manfaat praktis yang diharapkan oleh peneliti adalah adalah agar masyarakat (pembaca) dapat 


Kredo 3 (2020)
KREDO: Jurnal Ilmiah Bahasa dan Sastra
Terakreditasi Sinta 4 berdasarkan Keputusan Direktorat
Jenderal Penguatan Riset dan Pengembangan,
Kementerian Riset, Teknologi dan Pendidikan Tinggi
Republik Indonesia
Nomor: 23/E/KPT/2019. 08 Agustus 2019
https://jurnal.umk.ac.id/index.php/kredo/index

lebih kreatif dalam menggunakan ragam bahasa khususnya untuk melabeli dan memberikan nama pada toko atau kedai kopi.

\section{DAFTAR PUSTAKA}

Abdullah, Wakit. 2014. Etnolinguistik: Teori, Metode, dan Aplikasinya. Surakarta: UNS Press.

Alwi, Hasan dan Dendi Sugono. (editor). 2002. Telaah bahasa dan Sastra. Jakarta: Buku Obor

Aminuddin. 2008. Semantik Pengantar Studi Tentang Makna. Bandung: Sinar Baru Algensindo.

Aziz, Donny Khoirul. 2013. Akulturasi Islam dan Budaya Jawa. Fikrah, Vol. I, No. 2, Juli-Desember 2013 halaman 253-286

Chaer, Abdul. 2002. Pengantar Semantik Bahasa Indonesia. Jakarta: PT Rineka Cipta.

Chaer, Abdul. 2010. Kesantunan Berbahasa. Jakarta: Penerbit Rineka Cipta.

Cresswell, John W. 1994. Research Design: Qualitative and Quantitative Approaches. London:Sage

Cruse, D. Alan. 1991. Lexical Semantics. Cambridge: Cambridge University Press.

Djajasudarma, T. Fatimah. 1999. Semantik 2: Pemahaman Ilmu Makna. Bandung: Eresco

KKBI. 2016. https://www.kbbi.web.id/ Koentjaraningrat. 1993. Metode-Metode Penelitian Masyarakat. Jakarta: Gramedia PustakaUmum

Koentjaraningrat. 2005. Pengantar Ilmu Antropologi. Jakarta: PT. Rineka Cipta Mastuki HS.Islam, Budaya
Indonesia, dan Posisi Kajian Islam di Perguruan Tinggi Islam.KHAZANAH: Vol. XII. No. 01 Januari-Juni 2014 halaman 16-27

Kridalaksana, Harimurti. 2000. Politik Bahasa dan Politik Kebudayaan. Kajian Serba Linguistik untuk Anton Moeliono Pereksa Bahasa (Buku kumpulan artikel linguistic diedit oleh Prof. bambang Kaswanti Purwo). Jakarta: PT BPK Gunung Mulia.

Pateda, Mansoer. 2010. Semantik Leksikal. Jakarta: Rineka Cipta

Rahayu, S. 2019. Istilah-Istilah Penamaan Tempat Wisata di Kabupaten Karanganyar: Kajian Etnolinguistik. Sutasoma: Journal of Javanese Literature

Verhaar, J. W. M. 2001. Azas-Azas Linguistik Umum. Yogyakarta: Gajah Mada University Press.

Wardoyo, C. \& Sulaeman, A. 2017. Etnolinguistik Pada Penamaan Nama-Nama Bangunan Keraton Yogyakarta. Jurnal al Tsaqafa Volume 14, No. 01 